\title{
Resource Distribution in Mental Health Services: Changes in Geographic Location and Use of Personnel in Norwegian Mental Health Services 1979-1994
}

\author{
Per Bernhard Pedersen* and Solfrid Lilleeng \\ SINTEF Unimed NIS Health Services Research, Trondheim, Norway
}

\begin{abstract}
Background: During the last decades, a central aim of Norwegian health policy has been to achieve a more equal geographical distribution of services. Of special interest is the 1980 financial reform. Central government reimbursements for the treatment of in-patients were replaced by a block grant to each county, based on indicators of relative 'need'.

Aims of the study: The aim of this paper is to assess whether the distribution of specialized mental health services did take the course suggested by the proponents of the reform (i.e. a more equal distribution), or the opposite (i.e. a more unequal distribution) as claimed by the opponents.

Methods: Man year per capita ratios were used as indicators for the distribution of mental health services by county. Ratios were estimated for 'all personnel', and for MDs and psychologists separately. Man years were assigned to counties by location of services (i.e. in which county the services were produced), and by residence of users (i.e. in which county the services were consumed). Indicators of geographic variation were estimated using the standard deviation (STD) as a measure of absolute variation, and the coefficient of variation (CV) and the Gini index as indicators of relative variation. Indicators were estimated for 1979 , 1984, 1989 and 1994, based on data for all specialized adult mental health services in the country. Changes in distributions over the period were tested, using Levene's test of homogeneity. Results: Relative variations in the distribution of personnel by location of services were substantially reduced over the period, the $\mathrm{CV}$ being reduced by more than $50 \%$ for all groups. Variations in the personnel ratios by residence of users were smaller at the start of the period, and the reductions were also smaller. Still, relative variations were reduced by $20-35,40$ and $60 \%$ approximately for 'all personnel', MDs and psychologists respectively. In spite of a major increase in the supply of MDs and psychologists, absolute variations in the personnel ratios were in all cases either reduced, or fairly stable.

These results give little support to the views expressed by the opponents of the 1980 reform, although the main result seems to have been relocations in the production of services, more than redistributions in the consumption of services.
\end{abstract}

\footnotetext{
* Correspondence to: Per Bernhard Pedersen, SINTEF Unimed NIS Health Services Research, N-7465, Trondheim, Norway.

Email address: per.pedersen@unimed.sintef.no

Source of funding

Contract grant sponsor: The Norwegian Research Council

Contract grant sponsor: The Norwegian Ministry of Health and Social Affairs
}

Discussion: These results can be seen as a result of three aspects of the reform:

(1) Distributing government grants to counties in their capacity as users of services rather than producers of services. This shift has primarily facilitated relocations in the production of services.

(2) Relocation of services was also expected to produce a more equal distribution in the use of services, since reduced distances would increase accessibility. This, however, was counteracted by increased county control with use of services in other counties.

(3) Distribution of grants based on 'needs' rather than services produced was expected to produce a more equal distribution in the use of services. This effect seems to have been less than expected, probably because counties with high reimbursements under the old system also provided services to people from other counties.

Other policy reforms have, however, contributed to the results. These reforms include increased supply of personnel, de-institutionalization of services, regionalization/sectorization of services, and the establishment of smaller psychiatric units in general hospitals.

Policy implications: In recent years the 1980 reform has been under attack; partly due to alleged inequalities created by the system. As a result of the critique, government reimbursements for in-patient treatment have been reintroduced for general hospital services. In mental health services, more resources are distributed to specific projects.

According to this study, this shift in policy is based on faulty premises and might lead to greater inequalities in the future. Copyright (c) 2000 John Wiley \& Sons, Ltd.

Received 10 June 1999; accepted 15 February 2000

\section{Introduction}

\section{The 1980 Financial Reform}

During the last decades, a central aim of Norwegian health policy has been to achieve a more equal geographical distribution of health services. During the 1970s and early 1980s there was also a strong de-centralist tendency in Norwegian politics, aimed at transferring more control and responsibility for public services from central government 
authorities to locally elected authorities (for specialized mental health services, to the counties).

As a result of these policy developments, the mode of central government control for specialized health services was changed from 1980. The central government had previously financed about $50 \%$ of the expenditures through reimbursements for in-patient days. The number of institutions and the number of beds in these institutions were regulated through a plan for each county, approved by the central government. The government had authority for making changes in these plans. ${ }^{1-4}$

From 1980 onwards the counties were given full financial responsibility for all specialized health services to their own populations..$^{5}$ In order to finance these increased expenditures, the counties received a block grant, based on criteria for (relative) need. The central government retained the authority for making changes in the local plans, but this authority was seldom used. Central government did, however, retain and use the right to sanction new positions for MDs.

\section{Possible Consequences of the 1980 Financial Reform}

In the literature on local government equality and local autonomy are often considered contradictory aims. Local autonomy implies local discretion in the supply of services and will consequentially lead to variability between local units. According to the opponents of the new system (focusing on increased discretion at the county level), the block grant system would lead to increased inequality between counties in the supply of health services.

The proponents of the block grant system claimed, however, that the new system would give a more equal distribution of services between the counties. The old reimbursement system (based on in-patient days) favoured counties already having established a large volume of inpatient services. A distribution of grants based on needs instead of production would make it possible for counties with less developed services to expand these services and thus reduce inequalities. More important than local discretion was local ability (income) to finance services.

The 1980 reform represented a major change in the mode of implementing a national health policy, from direct (central) control through a centrally controlled planning system, to a decentralized system where central government control was basically limited to a few key factors (i.e. size of the block grants etc).

The purpose of this paper is to investigate whether the distribution of resources for mental health services did take the course suggested by the proponents of the reform (i.e. a more equal distribution of services), or the opposite (i.e. a more unequal distribution) as suggested by the opponents.

Two aspects of the distribution will be examined, the distribution of personnel by location of services, and the distribution of personnel by consumption of services.

\section{Previous Research on Geographic Variations in Health Services}

Since Edward Jarvis's work in the mid-19th century, the effects of distance on consumption of mental health services have been acknowledged. Jarvis's central observation, often referred to as 'Jarvis's law', says that, other things being equal, distance of a person's residence from a mental health facility is inversely related to the likelihood of using or being admitted to that facility. ${ }^{6}$ In more general terms, the question is how variations in the availability of health services resources influence the consumption of these resources.

In the last decades several studies have taken up this theme. Some studies have focused on variation in consumption between smaller (residence) areas within a catchment area, including distance to the health facilities as an independent variable (for an overview of this literature, see reference 7). In small area analysis, focus has been on variation in consumption between catchment areas, using resources in the catchment area as an independent variable (for a general overview, see references 8-10; for more recent work within mental health, see for instance references 11-20).

Underlying much of this work has been a concern with the distribution of resources. However, the questions asked have often been prescriptive rather than descriptive in nature: What level of resources is sufficient? What criteria should be used to achieve a fair distribution of resources?* Rather paradoxically, this has led to less attention on actual variation in resources used. Instead, elaborate techniques have been developed for 'controlling' the effect of resources when assessing the impact of 'needs' (morbidity, social indicators etc) on the use of health services.

As pointed out by White ${ }^{21,22}$ and Dear $^{23}$ in the field of medical geography and by Wennberg ${ }^{24}$ in the field of small area analysis, location of services will be influenced by many factors other than 'need' The purpose of this paper is to analyse the distribution of resources in order to assess how this is affected by central government policy.

In spite of the importance given to equality in the debate on the 1980 reform, only a few studies have been undertaken to investigate the effect on inter-county variations. ${ }^{25-28}$ Sørensen and Simonsen, ${ }^{29}$ studying inter-county variation in running expenditures by sector in Norway 1980-1990, found increased variation for health and social services over the first part of the period, and reduced variation over the last part of the period. Hagen and Sørensen ${ }^{30}$ found reduced inter-county variation in expenditures for general hospitals in Norway over the period 1986-92.

\section{Administrative Setting}

According to the Norwegian 1961 Mental Health Law, ${ }^{1}$ each county is responsible for providing specialized mental

\footnotetext{
* This focus can be seen already in the work of Jarvis himself, proposing
a system for locating psychiatric institutions based on distances, in order

* This focus can be seen already in the work of Jarvis himself, proposing
a system for locating psychiatric institutions based on distances, in order to reduce variations in the use of services. ${ }^{6}$
} 
health services to its own population (either by producing the services themselves, or by contracting services to other counties or private providers). Most services are also owned and run by the counties.

There are all together 19 counties, with a population ranging from 76000 in the county farthest north (Finnmark) to 500000 in the capital (Oslo). A locally elected assembly governs each county.

Mental health services account on average for $11 \%$ of the counties' net running expenditures; other services include general hospital services (35\%), high-school education (27\%) and roads and public transport (12\%) (1994). ${ }^{31-33}$ Services are mainly financed through government grants (46\%) and a local income tax (40\%). ${ }^{31}$ The level of the income tax is decided by the parliament, so for all intents and purposes, the total income of each county is controlled by the central government.

\section{Material and Methods}

\section{Using the Personnel Per Capita Ratio as Indicator of Resource Distribution}

Personnel in specialized adult psychiatric services at the end of the year (full time equivalents) were used as indicator of service resources. In addition to 'all personnel', data were gathered separately for two key personnel groups, MDs and psychologists. Services include psychiatric hospitals, psychiatric units in general hospitals, psychiatric nursing homes, psychiatric units in general nursing homes, halfway houses, day-centres and outpatient clinics, thus covering most specialized mental health services. Psychiatrists and psychologists in private practice are, however, not included.

Personnel was used as indicator, since staff is the dominant economic factor in the production of psychiatric services, alone responsible for $80 \%$ of the running cost, ${ }^{34}$ and since reliable accounts of total expenditures are not available for the whole period. For the last year (1994) however, comparison of per capita ratios for man years and gross running expenditure at the county level, and comparison of man years and gross running expenditures for each institution gave almost perfect correlation between the two indicators $(r>0.95)$.

\section{Measuring Location of Personnel}

Personnel was assigned to counties by the location of services and by the county of residence of users:

- Staff assigned by location of resources. Personnel at each institution were assigned to the county responsible for running the institution. Personnel in institutions run by the central government were assigned to the county in which the institution was located.*

\footnotetext{
* Until the mid-1980s a few mental health institutions were run by the central government. Seven per cent of the personnel worked in institutions run by the central government at the start of the period.
}

- Staff assigned by county of residence of users. Personnel at each institution were proportionally assigned to counties according to the resident county of users (inpatients and day-patients) on a specific day. $\dagger$ Personnel at the outpatient clinics were assigned to the county running the service.

Data were gathered for the years 1979, 1984, 1989 and 1994 , based on records for each institution. $\$$ Data cover the period the system of financing was in full operation.

\section{Data Analytic Procedures: Estimating Changes in Distributions}

In order to assess the relative distribution of resources, the personnel per capita ratios were estimated, i.e. personnel assigned to each county were compared to the adult population (18 years or older) in each county. $\S$

Three indicators of variation were estimated:

- the standard deviation (STD) and

- the coefficient of variation (CV) for the 'personnel ratio' (full time equivalents per capita 18 years or older) and

- the Gini index and the Lorenz curve for the distribution of personnel compared to the distribution of inhabitants (18 years or older).

The standard deviation is an easy comprehensible measure of distribution, but will vary with the absolute values (size and type of measurement). The CV was therefore included in order to compare subgroups and controlling for changes in volume of the workforce over time. The $\mathrm{CV}$ is defined as the standard deviation divided by the mean.

The CV for the 'personnel ratio' gives the same weight

$†$ For instance: hospital $\mathrm{N}$ had a staff of 150. At the end of the year, the hospital had 90 patients, 60 patients from county A and 30 from county B. 100 employees $(150 \times 60 / 90)$ are 'assigned' to county A, 50 to county B. \$ Statistics Norway provided data on personnel for the years 1979, 1984 and 1989. For 1994 the data was based on a file collected in co-operation by Statistics. Norway and SINTEF Unimed NIS. Data on the patient's county of residence were for 1979 and 1994 provided by Statistics Norway. For 1984 and 1989, data were based on a registration of all adult psychiatric patients carried out by SINTEF Unimed NIS. Data on population by county was provided by The Norwegian Social Science Data Services. Data from Statistics Norway were checked for completeness and consistency, using the previous and following years as points of reference.

$\S$ For several reasons we decided to use the total adult population rather than some factor of 'need' as a standardizing factor:

- The policy declarations put only marginal weight to differences in need, and the purpose of the study is to evaluate this policy.

- There have been significant changes in the patient population over the period. For instance, there has been a marked shift in the age distribution of patients at the psychiatric hospitals. ${ }^{35}$ If indicators of relative 'need' (based on actual patterns at the national level) are applied, different weights must be used for different years. This would obscure the analysis. It has elsewhere been documented that for the last year in the analysis (1994) standardizing for age and sex has a maximum effect on relative need of $\pm 2 \%$. $^{36}$

- With a possible exception for the two counties in the capital region, most counties include a mix of richer versus poorer and urban versus rural areas, so effects of social differences will be tuned down. In addition, although some Scandinavian studies have displayed a class gradient, ${ }^{37,38}$ most Scandinavian epidemiological studies ${ }^{39-42}$ do not display the social class gradient in mental illness rates found in British and North American studies. ${ }^{43-46}$ 
to all counties. In the Gini index results are weighted according to the population size. In addition, the Gini index is standardized, varying from zero (each individual receiving exactly the same amount of 'the good') to one (one individual receiving 'the good' alone).$^{47}$

Data covers all relevant units (i.e. data is not based on a sample). Given only 19 observations, test of significance will also easily lead to type II errors (i.e. not rejecting a false null hypothesis). Since indicators are based on point estimates, probability values ( $p$-values) will still be reported. The discussion of the results will, however, be based on a substantial, rather than a statistical interpretation.

The observations display a non-normal distribution. Instead of testing changes in the STD directly, Levene's test of homogeneity was used. Levene's test is based on the absolute deviations rather than the squared deviations. This makes the test criterion much less sensitive to long tailed distributions. To perform a Levenes' test the absolute deviation from the mean for each county and year in the period were computed. The null hypothesis being that the inter-county variation is on a constant level, the hypothesis of unequal inter-county variation over time is then tested using one-way analysis of variance of the absolute deviations for each year. ${ }^{48}$

In order to test changes in the relative inter-county variations (corresponding to the $\mathrm{CV}$ ), the same technique was applied. The average of the absolute deviations from the mean was, however, divided by the mean. To test the hypothesis of heterogeneity in the relative inter-county variation in the period, we again used a one-way analysis of variance of the deviations for each year. Details on the procedure are given in the Appendix.

\section{Results}

The results are presented in Table 1, giving the standard deviation (STD), the coefficient of variation $(\mathrm{CV})$ and the Gini index, for 'all personnel', MDs and psychologists respectively for the years 1979, 1984, 1989 and 1994. Included in the table are also the 1994/1979 ratios, plus $F$ values and probability values based on Levine's test of homogeneity. The absolute values used in estimating Levene's test are given in the appendix.

For all groups, relative variations in the distribution of personnel by location of services were reduced by more than $50 \%$. This also applied to the absolute variations for 'all personnel'. Despite an increase by $67 \%$ in the MD per capita ratio, and an increase by $200 \%$ in the psychologist ratio, absolute variations remained stable for psychologist and were actually reduced by $25 \%$ for MDs.

Turning to the distributions of personnel by residence of users, variations in the personnel ratios were smaller at the start of the period, and changes in variation were also smaller, compared to those found for distribution by location of services. Still, relative variations were reduced by 20 35, 40 and 60\% approximately for 'all personnel', MDs and psychologists respectively. The absolute variation for 'all personnel' was also reduced by almost $20 \%$, while absolute variations for MDs and psychologists remained fairly stable (10\% increase for psychologists), despite considerable increase in the personnel ratios over the period.

Figure 1 gives a graphical representation of the results for 'all personnel'. In the figure, the Lorenz curve (equivalent to the Gini index) for the distributions in 1979 and 1994 are displayed.* The distribution of personnel by location had the most uneven distribution at the outset (the Lorenz curve being farthest away from the diagonal), but displays a major reduction over the period. The distribution of personnel by residence of users was more evenly distributed at the outset, and the absolute reduction over the period is smaller. At the end of the period, distribution by location of services and by residence of users are almost identical (the Lorenz curves almost covering each other).

Figures 2 and 3 display the corresponding results for MDs and psychologists. Variations in the distribution by county of production are considerably reduced, while variations by county of use display somewhat smaller reductions. The two distributions are almost identical at the end of the period. Comparing the three figures, the psychologists display the most unequal distribution at the start of the period, and the most equal distribution at the end of the period.

\section{Discussion}

The purpose of this paper is to assess whether or not variations in the cross-county distributions of personnel have become smaller or greater, following the 1980 financial reform. To the extent changes in distribution can be attributed to the 1980 reform, the subsequent developments seems to support the view held by the proponents of the reform. Relative variations in the location of services have been substantially reduced for all groups. Relative variations in the distribution by residence of users have also been reduced, but the reductions are much smaller both for personnel in all and for MDs. In no cases did we find increased relative variation.

From a health policy perspective, reducing variations in the distribution of personnel by location of services can be seen as an independent goal. In most cases, however, reduced variation in the location of services will (in accordance with Jarvis's law) be seen as a mean to achieve reduced variation in the access to services, thereby reducing inequalities in the use of services.

Why then, do we find larger reduction in variation by location of services than use of services?

A central characteristic of the 1980 reform was that

\footnotetext{
* In the figures, the counties are sorted according to the personnel per capita ratio. If all counties receive the same amount of personnel (per capita), i.e. if we have a total equality in distribution, the curve will follow the diagonal. If one county received all the personnel, i.e. if we have a total inequality in distribution, the Lorenz curve would (almost) follow the horizontal and vertical lines. The closer the Lorenz curve approaches to the diagonal, the less inequality in distribution. The Gini index is defined as the area between the Lorenz curve and the diagonal compared to the total area of the triangle below the diagonal, and will vary between 1 (unequal distribution) and 0 (equal distribution). ${ }^{49}$
} 
Table 1. Variations in the distribution of personnel in adult mental health services 1979-1994. Standard deviation (STD) and coefficient of variation $(\mathrm{CV})$ for the personnel per capita ratios*. Gini index. F-values and $p$-values based on Levene's test (absolute deviations). All personnel, MDs and psychologists. Counties by location of services and residence of users

\begin{tabular}{|c|c|c|c|c|c|c|c|}
\hline & 1979 & 1984 & 1989 & 1994 & $\begin{array}{l}1994 / \\
1979\end{array}$ & $\begin{array}{c}\text { Levene's } \\
F \text {-value }\end{array}$ & $p$-value \\
\hline \multicolumn{8}{|c|}{ All personnel } \\
\hline STD & 16.8 & 13.0 & 9.1 & 7.7 & 0.46 & 3.491 & 0.020 \\
\hline $\mathrm{CV}$ & 0.52 & 0.36 & 0.25 & 0.21 & 0.40 & 4.574 & 0.005 \\
\hline Gini & 0.27 & 0.20 & 0.15 & 0.12 & 0.44 & & \\
\hline \multicolumn{8}{|c|}{ Residence } \\
\hline STD & 9.5 & 10.4 & 8.9 & 7.9 & 0.83 & 0.078 & 0.972 \\
\hline $\mathrm{CV}$ & 0.27 & 0.28 & 0.24 & 0.21 & 0.78 & 0.117 & 0.950 \\
\hline Gini & 0.17 & 0.16 & 0.14 & 0.11 & 0.65 & & \\
\hline \multicolumn{8}{|l|}{ MDs } \\
\hline \multicolumn{8}{|c|}{ Location } \\
\hline STD & 0.89 & 0.96 & 0.76 & 0.68 & 0.76 & 0.390 & 0.761 \\
\hline CV & 0.81 & 0.69 & 0.46 & 0.35 & 0.43 & 2.038 & 0.116 \\
\hline Gini & 0.38 & 0.33 & 0.23 & 0.18 & 0.47 & & \\
\hline \multicolumn{8}{|c|}{ Residence } \\
\hline STD & 0.64 & 0.83 & 0.65 & 0.62 & 0.97 & 0.110 & 0.954 \\
\hline $\mathrm{CV}$ & 0.53 & 0.57 & 0.38 & 0.31 & 0.58 & 0.748 & 0.527 \\
\hline Gini & 0.27 & 0.28 & 0.30 & 0.17 & 0.63 & & \\
\hline \multicolumn{8}{|c|}{ Psychologists } \\
\hline \multicolumn{8}{|c|}{ Location } \\
\hline STD & 0.37 & 0.34 & 0.42 & 0.39 & 1.05 & 0.541 & 0.656 \\
\hline $\mathrm{CV}$ & 0.82 & 0.51 & 0.41 & 0.26 & 0.31 & 10.862 & 0.000 \\
\hline Gini & 0.43 & 0.28 & 0.21 & 0.13 & 0.30 & & \\
\hline \multicolumn{8}{|c|}{ Residence } \\
\hline STD & 0.31 & 0.31 & 0.43 & 0.34 & 1.10 & 1.098 & 0.356 \\
\hline $\mathrm{CV}$ & 0.63 & 0.45 & 0.41 & 0.23 & 0.37 & 4.187 & 0.009 \\
\hline Gini & 0.34 & 0.25 & 0.21 & 0.12 & 0.35 & & \\
\hline
\end{tabular}

df: between years: 3 , within years: $72 . N=19$.

*Full-time equivalents at the end of the year per 10000 inhabitants 18 years and older.

central government grants were distributed to counties as consumers rather than producers of services. Counties, having used services produced in other counties, were in this way given a real choice between buying services or producing services themselves (at approximately the same cost). Creating jobs has been a major concern in Norwegian local politics. In addition, health policy has emphasized locating services closer to the users. Countries previously using services elsewhere, then, had both the means and motive for establishing services themselves. Counties producing services to other counties would, on the other hand, have to adapt capacity to reduced demand from other counties, or would otherwise have to bear the full costs. As a result, there was a levelling out of differences in personnel by location. Additional analysis revealed that the proportion of staff producing services for people from other counties was reduced from 13 to $5 \%$. This effect is independent of whether or not the reform led to a more equal distribution of government grants.

In accordance with 'Jarvis's law', relocation of services was expected to produce a more equal distribution in the use of services, since reduced distances would increase accessibility. The reform did, however also give the counties increased responsibility for the costs of providing services. A more equal distribution in the use of services would require real changes in the income distribution between counties (through income taxes or government grants), changes in the priority given to mental health services at the county level, or government interventions aimed at reducing inequalities. The effect of Jarvis's law was in this way countered by increased control by counties with total volume of services used.

The next question is whether the distribution of grants based on 'needs for services' rather than services produced led to a more equal distribution in the use of government grants. This effect seems to have been overestimated, since counties with high reimbursements under the old system also provided services to people from other counties.

The discussion has so far focused the on the 1980 reform. Unfortunately, data is not available for the period prior to 1979. Regardless of these limitations in the data, several changes in public policy got under way during the 1970s, and due to differences in time lag these might also have influenced the changes observed. Four factors are of particular 


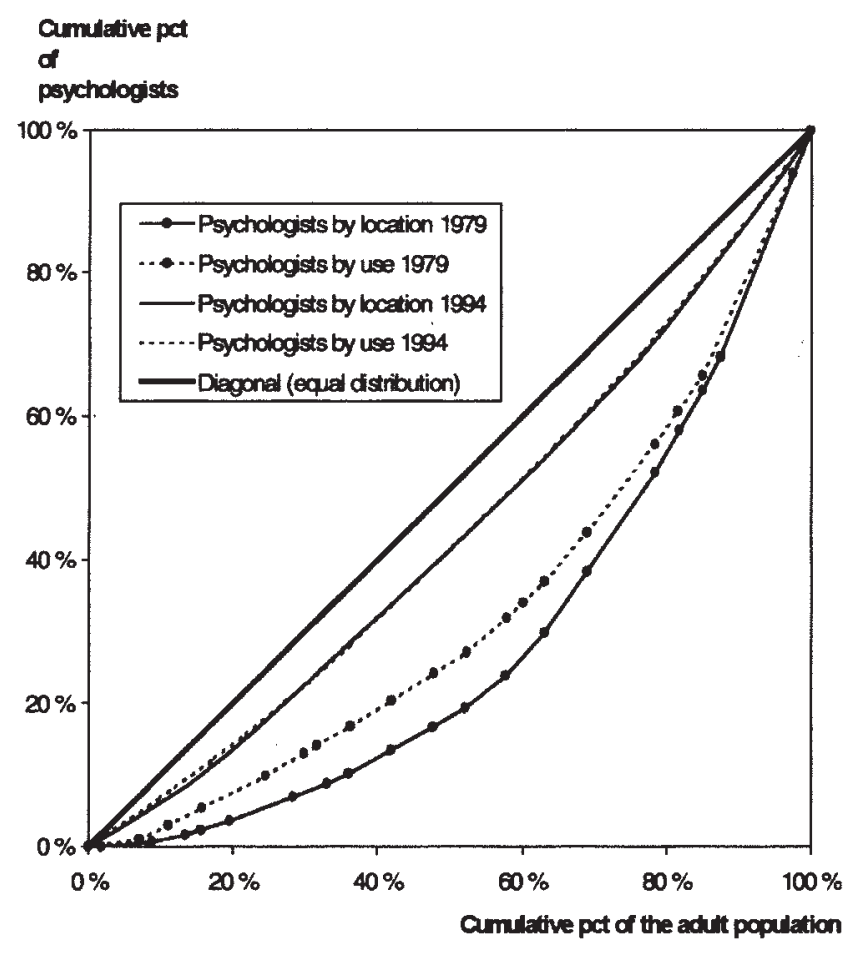

Figure 1. Lorenz curves for the distribution of all personnel in Norwegian adult mental health services 1979 and 1994. Location of services and residence of users by county

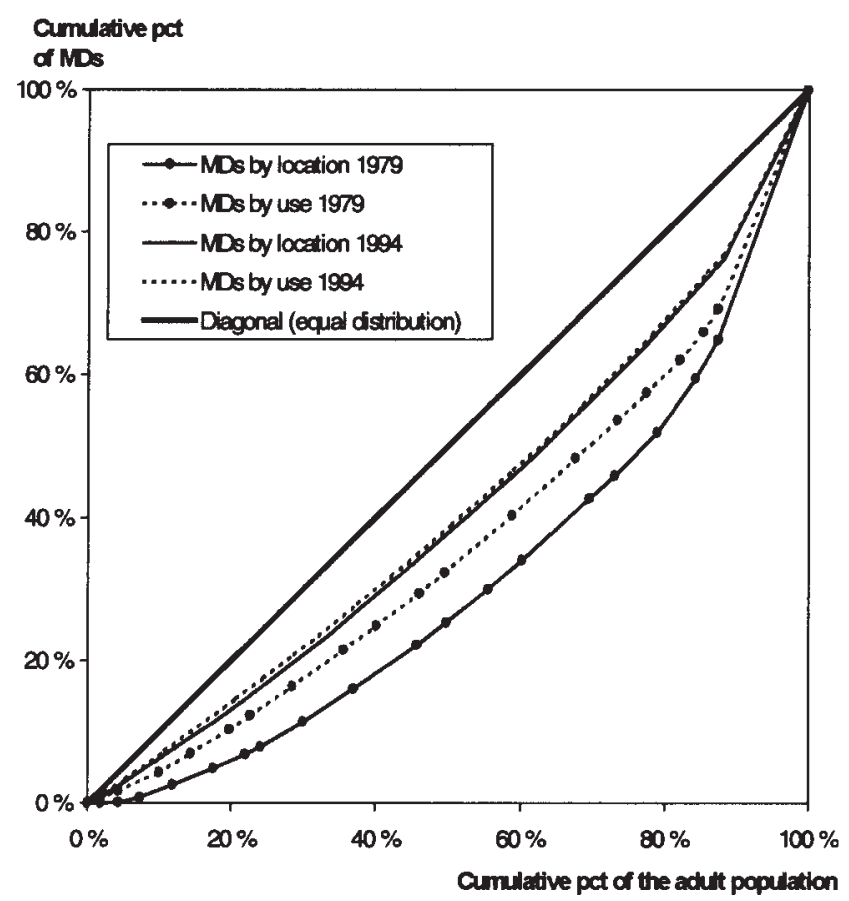

Figure 2. Lorenz curves for the distribution of MDs in Norwegian adult mental health services 1979 and 1994. Location of services and residence of users by county

interest: the supply of personnel, the de-institutionalization of services, the regionalization/sectorization of services and the establishment of smaller psychiatric units in general hospitals.

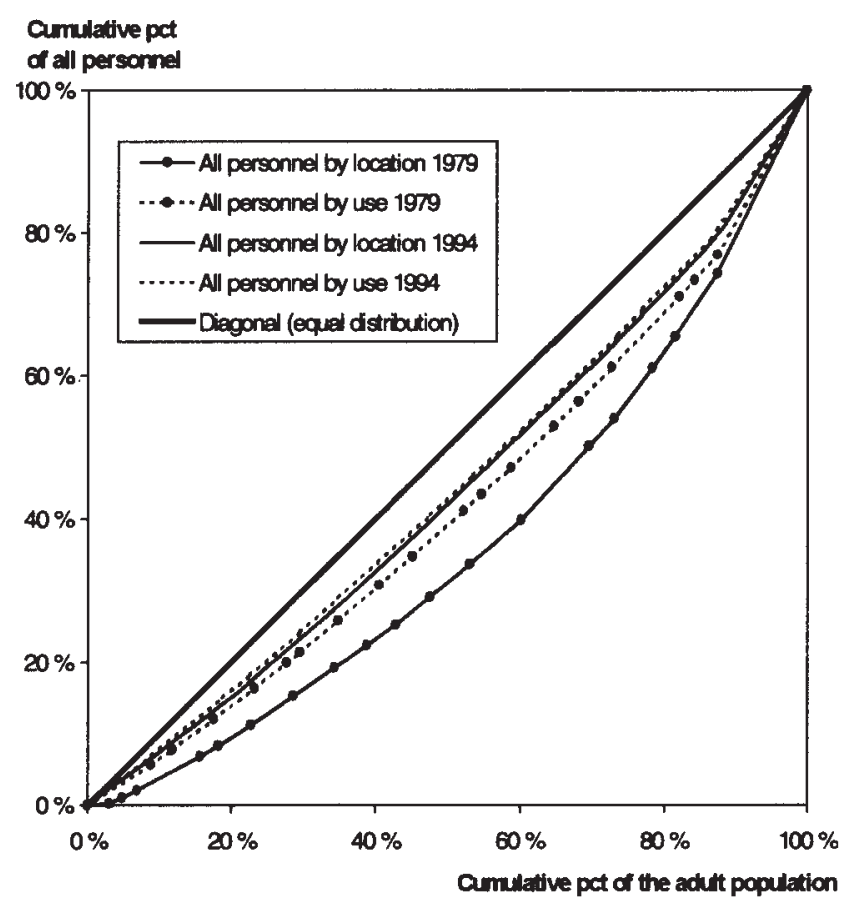

Figure 3. Lorenz curves for the distribution of psychologists in Norwegian adult mental health services 1979 and 1994. Location of services and of residence of users by county

\section{Increases in the Supply of Personnel}

Given the financial character of the 1980 reform, we would expect the reform to have the biggest impact on 'all personnel'. Total personnel costs account for $80 \%$ of total running costs. ${ }^{34}$ Increases for sub-groups, however, could be achieved through re-allocations between groups of personnel.

The national personnel per capita ratio (all personnel) was fairly stable over the period ( $6 \%$ increase), and increased personnel per capita ratio cannot explain reduced inequalities. The personnel ratio for MDs, though, increased by $67 \%$ and the ratio for psychologists tripled from 1979 to 1994 .

The effect of increases in the personnel per capita ratios on regional variations will depend on the demand for personnel: if all counties have vacant positions, the distribution of personnel will depend on the preferences of personnel. We would then expect an increase in supply to be distributed in the same way as existing personnel. Consequentially, the absolute variations (STD) will increase proportionally to the increase in the personnel ratios, while the relative variations $(\mathrm{CV})$ will remain constant. On the other hand, if some counties have already met their demand, increased supply will lead to a smaller increase in the absolute variations than in the personnel ratio, and a reduction in the relative variations.

In spite of a $67 \%$ increase in the MD ratio, the absolute variations (STDs) were constant (by residence) or reduced (by location). The CVs are in both cases substantially reduced. For the psychologists the absolute variations were stable and relative variations were substantially reduced, in spite of an increase of more than $200 \%$ in the personnel ratio. The increased supply of MDs and psychologists seems 
to have increased more than the demand, leading to a less uneven distribution.

Regional variations in personnel ratio for psychologists are now at the same level as those found for 'all personnel'. The variations in the MD ratios are still about 50\% higher. For 1996, it has elsewhere been documented that one quarter of the variation in the MD ratio is caused by vacant positions, while most positions for psychologists are filled. ${ }^{50}$ It should be noted that, in spite of a $67 \%$ increase in the MD ratio, central government control with new positions has been unable to eliminate the gap between positions and MDs available.

\section{De-institutionalization, Regionalization and the Establishment of Psychiatric Units in General Hospitals}

In Norway, the de-institutionalization of psychiatric services gained momentum from the early 1970s, the in-patient population (point prevalence ratio) having peaked in the early $60 \mathrm{~s}^{51}$ At the ideological level this process was motivated (and justified) by the ideal of integrating people with mental health problems in the local community.

Community based services, stressing contact between patient and community, and mental health services and other services, requires location of services close to the residence of patients. Distance alone inhibits the old asylums from fulfilling the requirements of community based services. A shift towards community based services will lead to a levelling out of variations, at least in terms of location of services, leading to the results observed.

The establishment of psychiatric units in general hospitals would also be expected to reduce geographic variations. At least in the Norwegian context, however, this factor is of limited importance. If we exclude units only providing outpatient services and units established through administrative changes alone (i.e. formally transforming psychiatric hospitals into general hospital units), psychiatric units in general hospitals still (1994) account for only $13 \%$ approximately of all personnel (7.5\% approximately in 1980). The effect on the geographic distribution of services is consequently limited.

The 1970s also witnessed other reforms in the field of health services. From 1970 the counties were given the formal responsibility for providing general hospital services (already established for mental health services through the 1961 mental health law. ${ }^{1}$ ) In a government White Paper, introduced in the mid-70s, ${ }^{4}$ regionalization (in mental health services often referred to as sectorization) was laid down as the main organizing principle. Each institution (or service) should have a defined responsibility for a (geographically) defined population, and the institutions/services should be located as close as possible to the population being served. Through these reforms the legal basis for a decentralized system of health services was laid down. Again, this policy would also match the results found.

In one sense the 1980 reform can be seen as a logical, although not necessary, means to achieve the aims of de- institutionalization, regionalization and the establishment of psychiatric units in general hospitals. These factors will all facilitate reduced geographical variations in the provision of services. The effect of establishing units in general hospitals, though, is limited. Establishing the separate effect of the 1980 reform will require further studies.

\section{Concluding Remarks}

The 1980 reform represented a major change in the mode of implementing a national health service policy, from direct (central) control through a centrally controlled planning system, to a decentralized system where central government control was basically limited to a few key factors (i.e. size of the block grants etc). In recent years the 1980 reform has been under attack, partly due to alleged inequalities created by the system. As a result, government reimbursements for in-patient treatment have been reintroduced for general hospital services, now covering $50 \%$ of the running cost. $^{52}$ In mental health services, more resources are distributed to specific projects. ${ }^{53,54}$

The question, then, is how well founded was the critique leading up to the recent changes? Looking at the location of services, relative variations were reduced by more than $50 \%$ over the period. We also found reduced variation in the relative distribution by location of users. The analysis gave little support to the view held by the critics of the financial reform introduced in 1980.

One question remains though; the 1980 reform was accompanied by other policy reforms working in the same direction. These include increased supply of personnel, the de-institutionalization and the sectorization/regionalization of services and the establishment of psychiatric units in general hospitals. Untangling the separate effect of the 1980 reform would require further studies, either by extending the time frame, through comparisons with other services or settings, or through studies of local-level decisionmaking processes.

Still, as far as the actual distribution of the mental health services is concerned, the recent policy shift seems to be based on faulty premises, and might lead to greater inequalities in the future.

\section{Acknowledgements}

The research presented in this paper was partly financed through a grant from The Research Council of Norway, partly by a grant from The Ministry of Health and Social Affairs. SINTEF Unimed NIS Health Services Research provided additional funding.

We will like to thank Professor Arnulf Kolstad, Professor Graham Thornicroft, Professor Per Arnt Pettersen, an anonymous reviewer and colleagues at SINTEF Unimed NIS for comments on previous drafts of the paper. We will also like to thank Trude Fagerli at Statistics Norway for supplying data, and Knut Sponberg, Psychiatric sector, Ullevål Hospital/County of Oslo for help with 'cleaning' 
data for Oslo. The Norwegian Social Science Data Service provided data on population in the counties. None of these persons and institutions are, however, responsible either for remaining deficiencies in data used, or for the conclusions based on the analysis of these data.

\section{Appendix}

Levene's test of homogeneity of variance is used in order to measure the absolute variation between counties and to compare the variation in the results in each year in the period 1979-94. In order to use Levene's test we compute the absolute deviations $\left|\mathrm{X}_{\mathrm{ij}}-\overline{\mathrm{X}}_{\mathrm{i}}\right|$ for each county $(j)$ and year $(i)$. To take into account the different levels of personnel ratio in the period, we modified the Levene test by computing a new figure, $\left|\mathrm{X}_{\mathrm{ij}}-\overline{\mathrm{X}}_{\mathrm{i}}\right| \overline{\mathrm{X}}_{\mathrm{i}}$, for each county $(j)$ and year $(i)$, see Table A. The absolute and relative deviations over the period were compared by a oneway ANOVA.

Table A. Distribution of personnel in adult mental health services 1979-1994. Absolute and relative deviations, Levene's $F$ and $p$-values for the personnel ratios (full time equivalents per 10000 inhabitants 18 years or older). All personnel, MDs and psychologists. Counties by location of services and residence of users

\begin{tabular}{|c|c|c|c|c|c|c|}
\hline & 1979 & 1984 & 1989 & 1994 & $\begin{array}{l}\text { Levene's } \\
F \text {-value }\end{array}$ & $p$-value \\
\hline \multicolumn{7}{|l|}{ All personnel } \\
\hline Absolute deviation & 12.7 & 8.8 & 6.0 & 4.5 & 3.491 & 0.020 \\
\hline Relative deviation & 0.39 & 0.25 & 0.16 & 0.12 & 4.574 & 0.005 \\
\hline \multicolumn{7}{|l|}{ Residence } \\
\hline Absolute deviation & 5.9 & 6.1 & 6.0 & 5.1 & 0.078 & 0.972 \\
\hline Relative deviation & 0.17 & 0.17 & 0.16 & 0.14 & 0.117 & 0.950 \\
\hline \multicolumn{7}{|l|}{ MDs } \\
\hline \multicolumn{7}{|l|}{ Location } \\
\hline Absolute deviation & 0.59 & 0.60 & 0.50 & 0.41 & 0.390 & 0.761 \\
\hline Relative deviation & 0.54 & 0.41 & 0.31 & 0.21 & 2.038 & 0.116 \\
\hline \multicolumn{7}{|l|}{ Residence } \\
\hline Absolute deviation & 0.40 & 0.47 & 0.41 & 0.37 & 0.110 & 0.954 \\
\hline Relative deviation & 0.33 & 0.31 & 0.25 & 0.18 & 0.748 & 0.527 \\
\hline \multicolumn{7}{|l|}{ Psychologists } \\
\hline \multicolumn{7}{|l|}{ Location } \\
\hline Absolute deviation & 0.31 & 0.27 & 0.35 & 0.27 & 0.541 & 0.656 \\
\hline Relative deviation & 0.69 & 0.39 & 0.34 & 0.18 & 10.862 & 0.000 \\
\hline \multicolumn{7}{|l|}{ Residence } \\
\hline Absolute deviation & 0.23 & 0.24 & 0.34 & 0.26 & 1.098 & 0.356 \\
\hline Relative deviation & 0.48 & 0.33 & 0.33 & 0.17 & 4.187 & 0.009 \\
\hline
\end{tabular}

df: between years: 3, within years: $72 . N=19$.

\section{References}

1. Lov om psykisk helsevern av 28.04.1961. Ministry of Social Affairs: Oslo.

2. Ot prp nr 36 (1967-68). Om lov om sykehus m.v. Ministry of Social Affairs: Oslo.

3. Lov om sykehus m.v. av 19.06.1969 No. 57.

4. St meld 9 (1974-75). Sykehusutbygging m.v. $i$ et regionalt helsevesen Ministry of Social Affairs: Oslo, 1974.

5. Ot prp nr 1 (1978-79) Om lov om endringer i lov av 19. juni 1969 om sykehus m.v. og $i$ andre lover, $i$ forbindelse med forslag om ny finansieringsordning for helseinstitusjoner. Ministry of Social Affairs: Oslo, 1978.

6. Hunter JM, Shannon GW, Sambrook SL. Rings of madness: service areas of 19th century asylums in North America. Soc Sci Med 1986; 23: $1033-1050$.

7. Philo C. Across the water: reviewing geographical studies of asylums and other mental health facilities. Health Place 1997; 3: 73-89.

8. Paul-Shaheen P, Clark JD, Williams D. Small area analysis: a review and analysis of the North American Literature. J Health Politics, Policy Law 1987; 12: 741-809.

9. Sanders D, Coulter A, McPherson K. Variation in Hospital Admission Rates: a Review of the Literature. King's Fund: London, 1989.
10. Stano M. Further issues in small area variation analysis. J Health Politics, Policy Law 1991; 16: 573-588.

11. Carr-Hill RA, Sheldon TA, Smith P, Martin S, Peacock S, Hardman G. Allocating resources to health authorities: development of method for small area analysis of use of inpatient services. BMJ 1994; 309: 1046-1049.

12. Hendryx MS, Rohland BM. A small area analysis of psychiatric hospitalizations to general hospitals. Effect of community mental health centres. Gen Hosp Psychiatry 1994; 16: 313-318.

13. Jarman B, Hirsch S, White P, Driscoll R. Predicting psychiatric admission rates. BMJ 1992; 304: 1146-1151.

14. Kelly A, Jones W. Small area variation in the utilization of mental health services: Implications for health planning and allocation of resources. Can J Psychiatry 1995; 40: 527-532.

15. Smith P, Sheldon TA, Martin S. An index of need for psychiatric services based on in-patient utilisation. Br J Psychiatry 1996; 169: 308-316.

16. Lelliot P, Jarman B, Bajeklal M, Glover GR. Commentaries on: an index of need of psychiatric services based on in-patient utilisation. Br J Psychiatry 1996; 169: 317-321.

17. Richman A, Boutilier C, Harris P. The relevance of sociodemographic and resource factors in the use of acute psychiatric inpatient care in the Atlantic Provinces of Canada. Psychol Med 1984; 14: $175-182$. 
18. Rosenheck R, Astrachan B. Regional variation in patterns of inpatient psychiatric care. Am J Psychiatry 1990; 147: 1180-1183.

19. Thornicroft G. Social deprivation and rates of treated mental disorder. Developing statistical models to predict psychiatric service utilisation. Br J Psychiatry 1991; 158: 475-484.

20. Thornicroft G, Brewin CR, Wing J (eds). Measuring Mental Health Needs. London: The Royal College of Psychiatrists - Gaskell, 1992

21. White, AN. Location analysis for public facilities: models, patterns and process. Ph.D. Thesis, University of Pennsylvania Department of Urban and Regional Planning, 1976.

22. White, AN. Accessibility and public facility location. Econ Geography 1979; 55: 18-35.

23. Dear M. Planning for mental health care: a reconsideration of public facility location theory. Int Reg Science Rev 1978; 3: 93-111.

24. Wennberg JE. Future directions for small area variations. Med Care 1993; 31: YS75-YS80.

25. Naustdalslid J. Stat og Lokal Styring. Norsk Institutt for by- og Regionforskning: Oslo, 1990.

26. Naustdalslid J. Statlig hokalstyring. Problemnotat om aktuelle forskningsoppgaver. Norsk Institutt for by- og Regionforskning: Oslo, 1992.

27. Vabo SI. Statlig styring av kommunesektoren. En kunnskapsoversikt. Norsk Institutt for by- og Regionforskning: Oslo, 1994.

28. Baldersheim H. Stat og kommune $i$ ein fors $\phi$ kstid. eit perspektiv på statlig styring $i$ forhold til kommunane. Norsk Senter for Forskning på Leiing, Organisasjon og Styring: Bergen, 1992.

29. Sørensen RJ, Simonsen M. Ulikheter $i$ kommunalt tjenestetilbud 1980-1990. BI Handelshøyskolen i Oslo: Sandvika, 1993.

30. Hagen TP, Sørensen R. Somatiske sykehustjenester. Prioritering av somatiske sykehustjenester i fylkeskommunene 1980-1992. Revidert utgave. Norsk Institutt for by- og Regionforskning: Oslo, 1995.

31. Statistics Norway. Strukturtall for kommunenes фkonomi 1994 [Struc tural Data from the Municipal Accounts 1994]. Oslo/Kongsvinger: Statistics Norway, 1996.

32. Nyland K. Utgifter til somatiske sykehustjenester. In Solstad K Petersen S $\varnothing$ (eds). SAMDATA Sykehus. Sammenligningsdata for somatiske fylkeshelsetjeneste 1994 [Comparative Data for General Hospital Services], SINTEF NIS Norwegian Institute for Hospital Research: Trondheim, 1995; Ch. 4: 67-85.

33. Pedersen PB. Utgifter til det psykiske helsevernet. In Pedersen PB (ed.). SAMDATA Psykiatri. Sammenligningsdata for psykiatrisk fylkeshelsetjeneste 1994 [Comparative Data for Psychiatric services 1994], SINTEF NIS Norwegian Institute for Hospital Research: Trondheim, 1996; Ch. 4: 111-138.

34. Kalseth J. Kostnadsnivået ved de voksenpsykiatriske institusjonene. In Pedersen PB (ed.). SAMDATA Psykiatri. Sammenligningsdata for psykiatrisk fylkeshelsetjeneste 1994 [Comparative Data for Psychiatric services 1994], SINTEF NIS Norwegian Institute for Hospital Research: Trondheim, 1996; Ch. 6: 159-180.
35. Gråwe RW, Pedersen $\mathrm{PB}$, Widen $\mathrm{JH}$. Changes in prevalence and comorbidity in a total population of patients with psychotic disorders in Norwegian psychiatric hospitals. Nord J Psychiatry 1997; 51: 127-132.

36. Pedersen PB. Beregning av relativt ressursbehov til voksenpsykiatrien på fylkesnivå. SINTEF UNIMED NIS Norwegian Institute for Hospital Research: Trondheim, 1996.

37. Ødegård $\varnothing$. The incidence of psychosis in various occupations. Int J Soc Psychiatry 1956; 2: 85-104.

38. Vaisanen E. Psychiatric disorders in Finland. Acta Psychiatr Scand Suppl 1975; 263: 22-33.

39. Leighton DC, Hagnell O, Leighton AH, Harding JS, Kellert SR, Danley RA. Psychiatric disorders in a Swedish and a Canadian community: An explorative study. Soc Sci Med 1971; 5: 189-209.

40. Hagnell O. A Prospective Study of Incidence of Mental Disorders. Svenska (Norstedt): Lundby, 1966.

41. Ringen S. Den sosiale forankring. Arbeidsnotat No. 82. Levekårsundersøkelsen: Bergen, 1976

42. Hagen H. Hvem blir pasienter i psykiatriske institusjoner? Norwegian Institute for Hospital Research: Trondheim, 1987.

43. Scwab JJ and Scwab ME. Sociocultural Roots of Mental Illness. Plenum: New York, 1978.

44. Hollingshead AB, Redlich FC. Social class and mental illness: A Community Study. Wiley: New York, 1958.

45. Dohrenwend BP, Dohrenwend BS. Social Status and Psychological Disorders: A Causal Inquiry. Wiley: New York, 1969.

46. Pilgrim D and Rogers A. A Sociology of Mental Health and Illness. Open University Press: Buckingham, 1993.

47. Hellevik O. Forskingsmetode $i$ sosiologi og statsvitenskap. 5 utg. Universitestsforlaget: Oslo, 1991.

48. Snedecor GW and Cochran WG. Statistical Methods, 7th edn. The Iowa State University Press: Ames, IA, 1980.

49. Cowell FA. Measuring inequality, 2nd edn. Prentice Hall-Harvester Wheatsheaf: Harlow, 1995

50. Pedersen PB, Ulleberg P, Sitter M, Lilleeng S. Personell. In Halsteinli V (ed). SAMDATA Psykiatri. Sammenligningsdata for psykiatrisk helsetjeneste 1996, SINTEF Unimed NIS Norwegian Institute for Hospital Research: Trondheim, 1997; Ch. 2: 45-100.

51. Pedersen PB. De-institusjonalisering av psykiatritjenesten $i$ Norge 1950-96. En statistisk dokumentasjon. SINTEF Unimed NIS Health Services Research: Trondheim, 1999.

52. Prisliste DRG 1999 med kodeveiledning, 2. versjon. Ministry of Health and Social Affairs: Oslo, 1998.

53. St meld 25 (1996-97). Apenhet og helhet. Om psykiske lidelser og tjenestetilbundene. Ministry of Health and Social Affairs: Oslo, 1997.

54. St prp 63 (1997-98). Om opptrappingsplan for psykisk helse 19992006. Ministry of Health and Social Affairs: Oslo, 1998 